Prymak Volodymyr, Doctor of Sciences (Law), Professor, Kyiv National University of Trade and Economics, 19, Kyoto str., Kyiv, 02156, Ukraine

ORCID: 0000-0001-9693-6353

Researcher ID: M-5163-2016

\title{
CIVIL LIABILITY ON THE PROTECTION OF VICTIMS OF WAR AND TERRORISM
}

The article is devoted to the specific features of functioning the mechanism of civil liability in legal relations that arise in connection with the need to protect the rights of victims of war and terrorist acts. The author pays priority attention to finding adequate ways of implementation in national legislation the provisions of international legal acts on compensation of the damage caused to the victims by the mentioned circumstances.

Keywords: national legislation, war, terrorist act, damages, civil liability.

Примак Володимир. Цивільно-правова відповідальність в контексті захисту прав осіб потерпілих від тероризму.

Статтю присвячено особливостям функиіонування механізму циивільноправової відповідальності в контексті правовідносин із захисту прав осіб, потерпілих від збройних конфліктів $і$ терористичних актів. Основну увагу автор приділяє визначенню належних способів імплементаиії у національному законодавстві положень міжнародно-правових актів щодо компенсаџії шкоди, спричиненої такого роду обставинами.

Ключові слова: національне законодавство, війна, терористичний акт, відшкодування шкоди, цивільно-правова відповідальність.

Relevance of research topic. The problem of protection of civil rights and interests, both in itself and in combination with various aspects of international legal protection of human rights, is constantly and quite justifiably the focus of attention of domestic scientists. However, the continuing state of armed aggression of the Russian Federation against Ukraine is of particular relevance to the raised issue. Because of the fighting in the area of anti-terrorist operation and the operation of the united forces, as well as due to the temporary occupation of a large part of the territory of our country, prerequisites were created for large-scale violations of personal non-property and property rights and interests of individuals and legal entities. 
Formulation of the problem. The provisions of international law on the need to create within the national legal systems various mechanisms of redress for the harm of victims of crime, terrorist acts, human rights and international humanitarian law violations (Good Practices, 2015) are based on the ideas of justice (Zegveld, 2003) and social solidarity (Banchuk et al. 2015). Without these ones national law could not to assert the primacy of human dignity (Hryshchuk, 2013). in the relevant sphere of social life. However, the legislation of Ukraine, designed to ensure full regulation of these compensatory relations, remains practically unformed.

Analysis of recent researches and publications. The issue of ensuring the state of Ukraine the right of victims to compensation for damage caused by acts of terrorism or as a result of hostilities has been actualized recently - with the beginning of the armed aggression of the Russian Federation against Ukraine (since 2014). In view of this, there is currently a lack of publications in domestic legal science on establishing the patterns of interaction between the rules of international and national law, designed to ensure the functioning of appropriate compensation mechanisms.

Presenting main material. Positive determining in the Law of Ukraine from 18.01.2018 № 2268-VIII «On the Features of State Policy for Ensuring the State Sovereignty of Ukraine in Temporarily Occupied Territories in Donetsk and Lugansk Regions» and in the Law of Ukraine from 15.04.2014 № 1207-VII «On Ensuring Rights and Freedoms Citizens and the Legal Regime in the Temporarily Occupied Territory of Ukraine» the responsibility of the Russian Federation as an aggressor state for violations of the rights and freedoms of a person and citizen defined in the Constitution and laws of Ukraine in a temporarily occupied Russian Federation territory, as well as the imposition on this state the obligation for compensation of material and moral damages caused as a result of temporary occupation to the state of Ukraine, legal entities, citizens of Ukraine, foreigners and stateless persons, unfortunately, remain unsecured at present sufficiently effective international legal and domestic legal instruments for the implementation of these regulations.

In addition, the rules of the aforementioned Laws of Ukraine are being in conflict with the provisions of the Law of Ukraine of 20.03.2003 № 638-IV «On Fight against Terrorism» and the Civil Protection Code of Ukraine, which contain blanket norms that potentially make the State liable for damage caused, accordingly, by a terrorist act or as a result of an emergency. Of course, many victims are using this, seeking to find a real source of compensation for their losses they suffered during hostilities in the East of our country.

In this context, it is important to take into account the content of international law on the protection of the rights of victims of crime (terrorist acts in particular) and violations of international humanitarian law, as well as internally displaced persons, who are largely focused on identifying appropriate forms of effective redress, among which issues of material compensation for property and non-material losses suffered by the victims (Basic Principles, 2005). 
Although the report prepared by J. Milquet to the President of the European Commission «Strengthening victims' rights: from compensation to reparation» demonstrates a certain shift of emphasis towards the most comprehensive use of the various forms of restoration of the violated rights of a wider range of victims of crime, in the European legal area the problems of determining the subjects of the right to compensation, its size (introduction of fair compensation schemes), the grounds or criteria for the emergence of the right to receive compensation from the state, terms and sources of making such payments remain relevant (and not only in connection with inability to meet the relevant requirements at the expense of direct harm causer) (Milquet, 2019).

It is noteworthy that the practical solution of these problems and the realization of tasks related to the restoration of the rights of victims of crimes and violations of international law, as well as internally displaced persons, lies predominantly in the field of civil liability and, it is possible, some related legal institutions, for the purposes of which include social protection of victims precisely by compensation for the damage they caused.

However, it is primarily a tort liability that results from the violation of absolute property and personal non-property rights - a matter only in determining the cause of the harm (it may be directly a criminal or a state whose law enforcement agencies have failed to prevent the act of a terrorism or aggressor state) or another subject (of the same state in whose territory the terrorist act occurred, certain international funds or national compensation funds - already as public law entities), which appears as an accountability though not committed any illegal actions that could cause damage, that is obliged to compensate.

So as in Art. 2.101 Principles of European Tort Law (hereinafter referred to as «PETL») emphasize the need for compensation for property and non-pecuniary damage caused by a breach of a legitimate interest (Principles of European Tort Law), and in accordance with paragraph 20 of the Basic Principles and Guidelines on the Right to a Remedy and Reparation for Victims of Gross Violations of International Human Rights Law and Serious Violations of International Humanitarian Law «compensation should be provided for any economically assessable damage, as appropriate and proportional to the gravity of the violation and the circumstances of each case, resulting from gross violations of international human rights law and serious violations of international humanitarian law, such as: (a) Physical or mental harm; (b) Lost opportunities, including employment, education and social benefits; (c) Material damages and loss of earnings, including loss of earning potential; (d) Moral damage; (e) Costs required for legal or expert assistance, medicine and medical services, and psychological and social services».

However, the customary provisions of international law concern only that «a State shall provide reparation to victims for acts or omissions which can be attributed to the State and constitute gross violations of international human rights law or serious violations of international humanitarian law» (Basic Principles, 2005). 
In other words, the state as the violator of the norms of international law bears responsibility for its own unlawful acts. That is why her liability is unconditionally based on the principle of full redress.

However, actions of the state of Ukraine to repel external aggression and restoration of sovereignty over temporarily occupied territories, counteraction to terrorism, etc. are exactly legitimate actions. In these cases (again, in the absence of dishonesty or disproportionateness in the actions of the representatives of the state), the forms and the limits of compensatory protection of the victims from hostilities and terrorist acts have to be defined in special legislation. At the same time, the inadequacy of the interpretation and application of its norms in the jurisprudence may give rise to false conclusions about the violation by the state the national legal norms and provisions of the Convention on the Protection of Human Rights and Fundamental Freedoms.

It should be emphasized that the Law of Ukraine of 06.03.2003 № 638-IV «On Fight against Terrorism» does not provide for material liability of the State of Ukraine in connection with the conduct of an anti-terrorist operation as a set of legitimate actions that could cause property and moral harm. However, it seems that domestic jurisprudence does not generally regard this fact. Therefore without a proper legal assessment remains the question about the presence in the actions of a potential subject of liability, not only unlawfulness, but also another objective condition of civil liability a causal link between the behavior of the offender and the harm caused by it. After all, causers of harm can be different persons, public-legal entities, their bodies, officials, armed formations, etc.

Separation of causations that are different from one another is an effective safeguard for the nowadays widespread mixing of hostilities, terrorist acts and emergencies in the political and legal space of Ukraine as objective circumstances, legal facts, as well as inherent to them legal regimes. Instead, due to the proposed emphasis on the certain causation, hostilities within the framework of an anti-terrorist operation will remain precisely military actions (collisions of elements of the armed organization of two states) as well in terms of determining the proper legal regime for damages and will not be interpreted as a plurality of terrorist acts or emergencies.

Most often, victims of hostilities related to the armed aggression of the Russian Federation against Ukraine as a normative basis of their claims to the State of Ukraine for compensation of property damage caused in the area of anti-terrorist operation and operations of the combined forces, refer to the norms of Art. 19 of the Law of Ukraine of 20.03.2003 № 638-IV «On Fight against Terrorism». They stipulate that: a) compensation for damage caused to citizens by a terrorist act shall be carried out at the expense of the State Budget of Ukraine in accordance with the law and with a subsequent recovery of the amount of such compensation from the persons who caused the damage in the manner prescribed by law; b) compensation for damage caused to an organization, enterprise or institution by a terrorist act shall be carried out in the manner prescribed by law. 
However, the Verkhovna Rada of Ukraine has not yet adopted a special law specifying the mechanism of compensation for the damage caused by a terrorist act. After all, the provisions of Art. 19 of the Law of Ukraine of 20.03.2003 № 638-IV «On Fight against Terrorism» are not the norms of direct action, since unlike most legal norms that stipulate direct responsibility of the state or territorial communities for actions of «third parties» (state bodies and bodies local self-government, their officials), neither defines the limits of such responsibility, nor its grounds and conditions.

Given the magnitude of the losses suffered by Ukrainian residents during hostilities in the East of our country, the implementation of other approach could lead to such a heavy financial burden that such jurisprudence could turn into an independent source of threat to Ukraine's national security.

Various elements of the mechanism of civil liability are covered by international legal documents that determine the principles of compensation for harm to victims of crime, terrorist acts, significant violations of human rights and international humanitarian law. For example, the European Convention on the Compensation of Victims of Violent Crimes of 24.11.1983 (Art. 2) (European Convention, 1983) implies that the state must assume compensation for the harm caused to those victims who have sustained serious bodily injury or impairment of health directly attributable to an intentional crime of violence and the dependents of persons who have died as a result of such crime. Moreover, the corresponding obligation arises in the absence of other sources of compensation.

Thus, at the international legal level, the range of special torts or factual grounds for imposing on a State a duty to compensate victims of crime is limited. In line with B. Emmerson's conventional approach, that drawn in report to the UN Human Rights Council on the fundamental principles of protecting the human rights of victims of terrorism, it is reasonable to consider the State's obligation to fully compensate victims of that category in two specific cases: when in the context of a terrorist act or the threat of its perpetration, the representatives of the state are directly or indirectly responsible for the violation of the human right to life; in the case of death or serious injury (Emmerson, 2012).

The outlined approach seems to be a balanced and consistent fundamental provision of tort law, according to which the level of compensation for damages depends on the value of certain interests, and therefore the most intense protection should be given to such personal non-material benefits, as life, physical and mental health, human dignity and freedom are obtained (Art. 2: 102 PETL) (Principles of European Tort Law).

Against this background, the attempts to shift the burden of compensation for any property damage caused by hostilities in the area of anti-terrorist operation and the operation of the combined forces, including the destruction of property belonging to victims, appear to be unjustified.

By the way, the same European Convention for the Compensation of Victims of Violent Crimes of 24.11.1983, in the Articles 4 and 5 (European Convention, 1983), 
provides for the possibility of limiting the scope of state liability - both in terms of determining the extent of property damages to be recovered and in the marginal amount of probable compensation. On the one hand, compensation should cover at least the loss of earnings, the cost of medicines and hospitalization, the burial and maintenance of the dependents of the deceased. On the other hand, the compensation regime may set upper and lower limits for compensation for all or part of the damage. In other words, we can talk about the admissibility of establishing a regime of partial liability of the state, and therefore the limitation of the principle of full compensation for the damage caused. And all these aspects should be reflected in the special law, which the legislator refers to in Art. 19 of the Law of Ukraine of 20.03.2003 № 638-IV «On Fight against Terrorism».

In addition, under the European Convention on the Compensation of Victims of Violent Crimes of 24.11.1983 (European Convention, 1983), compensation for harm may be reduced or canceled in the light of the applicant's financial situation, conduct, and cases where full or partial compensation is contrary «to a sense of justice or to public policy». It generally introduces the broadest discretionary approach, which covers, among other things, the situation of the victim's «counter-fault» in tort.

Draws attention to the fact that, in addition to the European Convention on the Compensation of Victims of Violent Crime of 24.11.1983 (European Convention, 1983), the Declaration of Basic Principles of Justice for Victims of Crime and Abuse of Power, adopted by the UN General Assembly on 29.11.1985, specifically emphasizes the recognition of victims non-pecuniary damage, thereby implicitly securing for them the right to compensation for the personal non-pecuniary loss they have suffered. Therefore, the question of the grounds and amount of compensation for non-pecuniary damage should also be addressed in special legislation, which would establish state's compensation for victims of crime, terrorist acts, as a result of violations of human rights and international humanitarian law (in particular the law that have to be adopted by the Verkhovna Rada of Ukraine to implement the provisions of Art. 19 of the Law of Ukraine of 20.03.2003 № 638-IV «On Fight against Terrorism').

Conclusion. Based on the foregoing, we can draw the following conclusions.

1. In the context of external aggression and in terrorist acts commission, the mechanism of civil liability is subject to certain transformations, related, first of all, to the fixing of special grounds, conditions and limits of its application, circumstances leading to discharge of liability, and the possible determination of distinct from the direct causer of the damage subjects of the obligation for its compensation.

2. There are no direct-action legal rules in the system of law of Ukraine that would fix the mechanism of compensation for damage caused by a terrorist act at the expense of the state. Provisions of Art. 19 of the Law of Ukraine of 20.03.2003 № 638-IV «On Fight against Terrorism» and Art. 85 of the Code of Civil Protection of Ukraine in such legal situations cannot be applied due to the absence of special laws mentioned in their texts. At the same time, the norms of Art. 86 of the Civil Protection Code of Ukraine, as well as the Code in general, extends exclusively to the legal 
relations expressly stated therein concerning the protection against emergencies caused by the consequences of terrorist acts.

3. National legislation on the compensatory protection of victims of war, crimes (terrorist acts in particular), human rights and international humanitarian law violations should provide for the overriding imposition on the State of the obligation to compensate for the damage caused by unlawful acts of other entities in the form of property and non-pecuniary damage by death or grievous damage to the health of the victims. In the special laws, reasonable restrictions on the action in the relevant field of civil relations inherent in the tort law principles of guilt and full compensation for harm should be established, as well as the peculiarities of the interaction of substantive and procedural guarantees for the protection of the victim's and the state's interests in the relationships with the direct causers of damage.

\section{REFERENCES}

1. Good Practices in Supporting Victims of Terrorism within the Criminal Justice Framework. New York : United Nations, 2015. P. 43-49. Retrieved from https://www.unodc.org/documents/terrorism/Publications/Good\%20practices\%20on\% 20victims/good_practices_victims_E.pdf.

2. Zegveld, L. (2003). Remedies for victims of violations of international humanitarian law. International Review of the Red Cross. 2003. P. 498. Retrieved from https://www.icrc.org/en/doc/assets/files/other/irrc_851_zegveld.pdf.

3. Banchuk, O. A., Dmytriieva I. O., Malyshev B. V., Saidova Z. M. (2015). Vidshkoduvannia poterpilym vid nasylnytskykh zlochyniv: yevropeiski standarty i zarubizhne zakonodavstvo / za zah. red. O. A. Banchuka. Kyiv : Moskalenko O. M., P. 46, 48, 50, 52. [in Ukrainian].

4. Hryshchuk, O. V. (2013). Ideia spravedlyvosti u pravi: filosofsko-pravovyi vymir. Naukovyi visnyk Chernihivskoho universytetu. Pravoznavstvo. Vyp. 644. P. 36-39. [in Ukrainian].

5. Basic Principles and Guidelines on the Right to a Remedy and Reparation for Victims of Gross Violations of International Human Rights Law and Serious Violations of International Humanitarian Law (adopted and proclaimed by General Assembly resolution 60/147 of 16 December 2005). Retrieved from https//www.ohchr.org/ EN/ProfessionalInterest/Pages/RemedyAndReparation.aspx.

6. Milquet, J. (2019). Strengthening victims' rights: from compensation to reparation. Retrieved from https://ec.europa.eu/info/sites/info/files/strengthening victims_rights___from_compensation_to_reparation.pdf.

7. Principles of European Tort Law. Retrieved from http://www.egtl.org/

8. European Convention on the Compensation of Victims of Violent Crimes of 24.11.1983. URL: https://rm.coe.int/1680079751.

9. Emmerson, B. (2012). Report of the Special Rapporteur on the promotion and protection of human rights and fundamental freedoms while countering terrorism. Retrieved from https://undocs.org/A/HRC/20/14. 